\title{
Sakarya Nehir Sakarya Nehir Sedimentinden İzole Edilen Aktinobakterilerin Antimikrobiyal ve Bitki Gelişim Teşvik Edici Özelliklerinin Belirlenmesi
}

\author{
Uğur ÇíĞDEM ${ }^{1}$, Ayten KUMAŞ², Fadime ÖZDEMIR KOÇAK ${ }^{3 *}$
}

\section{$\ddot{\mathbf{O z}}$}

Biyoaktif bileşik üretim potansiyeli yüksek olan aktinobakteriler antibiyotik, antitümör ajanı, bitki gelişimini teşvik eden faktörler ve enzimler üretebilmektedirler. Yeni biyoaktif bileşiklerin keşfi için faklı ekstrem ortamlardan izolasyon çalışmaları yapılmaktadır. Bu çalışmada, Sakarya Nehir kaynağının sedimentinden ilk kez aktinobakteri izolasyonu ve bu bakterilerin ürettiği farklı bioaktif metabolitlerin varlığı araştırlmıştır. Antimikrobiyal aktivite deneylerinde Gram pozitif, Gram negatif bakteriler, maya ve funguslar kullanılmıştır. İzolatların azotu (N) fikse edebilme inorganik fosfatı çözebilme yeteneklerine, indol asetik asit (IAA) üretebilme ve kazeinaz aktivitelerine bakılmıştır. 17 aktinobakteri izolatının 16S rDNA analizleri sonucunda, izolatlar Micromonospora sp., (14), Saccharomonospora sp. (2) ve Cellulomonas sp. (1) olarak tanımlanmıştır. Elde edilen sonuçlarda, Micromonospora izolatlarının Gram pozitif bakterilere, maya ve funguslara karşı etkin olduğu belirlenmiştir. 12 izolatın N'u fikse edebildiği, 7 izolatın IAA üretebildiği, 2 izolatın kazeinaz aktivitesine sahip olduğu görülmüştür. Antimikrobiyal özellikleri açısından yüksek aktiviteye sahip olanların iyi birer farmasötik aday olabileceği ve bitki gelişimini teşvik edici potansiyele sahip izolatların da tarım alanında biyogübre olarak kullanım potansiyeline sahip olduğu düşünülmektedir. Ayrıca, 16S rDNA dizi analizleri sonucunda 2 Micromonospora, Saccharomonospora sp. ve Cellulomonas sp. Suşlarının yeni birer tür olması söz konusudur.

Anahtar Kelimeler: Aktinobakteriler, Antimikrobiyal aktivite, Bitki gelişimini teşvik özellikleri, 16S rDNA analizi

\section{Determination of Antimicrobial and Plant Growth Promoting Properties of Actinobacteria Isolated from Sakarya River Sediment}

\begin{abstract}
Actinobacteria with high bioactive compound production potential can produce antibiotics, antitumor agents, factors that promote plant growth and enzymes. Isolation studies from different extreme environments are carried out for the discovery of new bioactive compounds. In this study, isolation of actinobacteria from the sediment of the headwaters of the River Sakarya and screening of their different bioactive metabolites were firstly performed. Gram positive, Gram negative bacteria, yeast and fungi were used in antimicrobial activity assay. The ability to (N) fix nitrogen, to dissolve inorganic phosphate, to produce indole acetic acid (IAA), and caseinase activities of isolates were investigated. As a result of 16S rDNA analysis of 17 actinobacteria isolates, the isolates were defined as Micromonospora sp., (14) as Saccharomonospora sp. (2) and as Cellulomonas sp. (1). In the results obtained, it was revealed that Micromonospora isolates have effective activity against Gram positive, yeast and fungi. 7 of the isolates could produce IAA and 12 of them could fix $\mathrm{N}$ and while 2 of the isolates have caseinase activity. The results obtained demostrated that those with high activity in terms of antimicrobial properties will can good pharmaceutical candidates. Isolates that have the potential to stimulate plant growth are also thought to have the potential to be used as biofertilizers in agriculture. In addition, as a result of $16 \mathrm{~S}$ rDNA sequence analysis, it is possible that 2 Micromonospora sp., Saccharomonospora sp. and Cellulomonas sp. strains are new species.
\end{abstract}

Keywords: Actinobacteria, Antimicrobial activity, Plant growth promoting, 16S rDNA analysis.

${ }^{1}$ Eskişehir Osmangazi Üniversitesi, Biyoteknoloji ve Biyogüvenlik Anabilim Dalı, Eskişehir, Türkiye, ugur.cigdem@hotmail.com ${ }^{2}$ Bilecik Seyh Edebali Üniversitesi, Biyoteknoloji Uygulama ve Araştırma Merkezi, Bilecik, Türkiye, happy_ayten@hotmail.com ${ }^{3}$ Bilecik Seyh Edebali Üniversitesi, Hemşirelik Bölümü, Sağlık Bilimleri Fak., Bilecik,Türkiye, fadime.ozdemirkocak@bilecik.edu.tr 


\section{Giriş}

Aktinobakteriler, genomlarında yüksek guanin ve sitozin (GC) içeriğine sahip olan Grampozitif bakterilerdir. Actinobacteria şubesi, mevcut bakteri domaini içerisindeki en büyük taksonomik birimlerden biridir (Ludwig ve ark., 2012). Aktinobakteriler, Streptomyces ve Streptomyces dişındakiler (nadir Aktinobakteriler) olarak iki ana gruba ayrılabilir. $\mathrm{Bu}$ mikroorganizmaların çoğunluğu hem karada hem de su (deniz dahil) ekosistemlerinde yaygın olarak bulunan serbest yaşayan organizmalardır (Macagnan ve ark., 2006).

Doğal bileşiklerin en önemli kaynaklarından biri aktinobakterilerdir ve bu grup mikroorganizmalardan elde edilen bileşiklerin ise \% 75'inin üreticisi Streptomyces cinsidir. Kalan \% 25'lik kısımı ise nadir aktinobakterilerden elde edilmektedir (Baltz, 2006). Son yıllarda artan bakterilerdeki çoklu ilaç dirençliliği ve doğal ürünlerin biyoteknolojik kullanımlardaki artışı nedeniyle yeni metabolit arayışlarında da artış meydana gelmiştir (Ribeiro ve ark., 2020). Streptomyces en çok taranan ve doğal metabolit açısından çalışılan grup olması nedeniyle yeni elde edilen Streptomyces izolatlarından benzer metabolitlerin eldesi gerçekleştirilebilmektedir. $\mathrm{Bu}$ nedenle farklı aktinobakterilerin izolasyonuna ve metabolit taramasına yönelim artmıştır. Tarama çalışmalarında en çok toprak çalışıldığı için deniz, göl ve nehir sedimenti (Guan ve ark., 2020; Veyisoglu ve ark., 2020, Özcan, 2019), endofitik bitki kök, gövde ve yaprak dokuları (Özdemir Koçak, 2019), volkan krateri (Tapia-Vázquez ve ark., 2020) gibi farklı ekosistemlerden izolasyon çalışmalarında artış meydana gelmiştir. Jose ve Jha'nın deniz sedimentinden yaptıkları izolasyon çalışmasında Glycomycetaceae, Micromonosporaceae, Nocardiaceae, Nocardiopsaceae, Pseudonocardiaceae, Streptomycetaceae ve Thermomonosporaceae familyalarına ait aktinobakteri izolasyonu gerçekleştirilmiştir. Bu çalışmada elde edilen nadir aktinobakteriler sekonder metabolit biyosentezi açısından incelenmiş ve oldukça yüksek potansiyele sahip oldukları belirlenmiştir (Jose ve Jha, 2017). Azman ve arkadaşlarının yaptığı derleme çalışmasında da, sadece tropikal kıyı bataklık bölgesi rizosferinden, sedimentinden, toprak ya da bitkilerinden elde edilen Micromonospora, Saccharomonospora, Actinomadura, Salinospora ve Jishengella gibi nadir aktinobakterilerin ve onlardan elde edilen metabolitlerin üzerinde durulmuştur (Azman ve ark., 2015).

Mikroorganizmalar bitki gelişimini doğrudan ya da dolaylı yollarla teşvik edebilirler. Doğrudan farklı fitohormon üretimleri, fosfatı çözebilmeleri, $\mathrm{N}$ fikse edebilmeleri gibi özelliklerle sağlarken antifungal aktiviteleri ile hastalıkları inhibe ederek dolaylı olarak etki gösterirler. Aktinobakteriler ürettikleri farklı doğal bileşikler sayesinde doğada bir çok canlı grubu ile simbiyotik ilişki kurabilmektedirler. Streptomyces spp. (Gong ve ark., 2018; Özdemir Koçak, 2019), Micromonospora endolithica (El-Tarabily ve ark., 2008), Cellulononas sp. (Güneş ve ark., 2021) gibi aktinobakterin bitkilerle olan simbiyotik ilişkileri ve farklı bitkilerin gelişimini arttırıcı özellikleri üzerinde 
çalışmalar bulunmaktadır.

Bu çalışmada, Sakarya Nehir kaynağının doğduğu alandan alınan sedimentlerden aktinobakteri izolasyonu ve sonrasında elde edilen izolatların 16S rDNA gen bölgesi dizileme çalışmaları ile moleküler tanımlamaları yapılmıştır. Elde edilen izolatlar doğal metabolit varlığı açısından incelenmiştir. Bu izolatların antimikrobiyal aktivite ve bitki geşimini teşvik edici özellikleri (IAA, inorganik fosfatı çözebilme, N fiksasyonu ve kazaeinaz aktivitesi) belirlenmiştir. Bu çalışma, Sakarya Nehir kaynağıın Aktinobakteri çeşitliliğinin belirlendiği ve elde edilen izolatların farklı biyoteknolojik özelliklerinin incelendiği ilk çalışmadır.

\section{Materyal ve Metot}

\subsection{Sedimentten Mikroorganizma İzolasyonu}

Çalışma kapsamında Eskişehir ili'nin Çifteler ilçesi'nde bulunan Sakarya Nehri kaynağının 4 farklı bölgesindenalınan sediment örnekleri konumlarına göre numaralandırılmış, steril cam kavanozlara alınmış ve laboratuvara getirilerek izolasyon amacıyla kullanılmıştır (Tablo 1).

Tablo 1. İzolasyon çalışması için örneklerin alındığı bölgeler ve bazı özellikleri

\begin{tabular}{cccc}
\hline $\begin{array}{c}\text { Örneklerin } \\
\text { Kodları }\end{array}$ & $\begin{array}{c}\text { Sedimentin Alındı̆̆ } \\
\text { Bölge }\end{array}$ & $\begin{array}{c}\text { Sedimentin } \\
\text { Alındı̆̆ Derinlik }\end{array}$ & $\begin{array}{c}\text { Sedimentin } \\
\text { Alındı̆̆ } \mathbf{~} \\
\text { Noktanın pH'sı }\end{array}$ \\
\hline S1 & $\begin{array}{c}\text { Güneş görmeyen bölge, } \\
\text { yosun kaplı alan }\end{array}$ & $1 \mathrm{~m}$ & 7.0 \\
\hline $\mathbf{S 2}$ & Az güneşli bölge & $\begin{array}{c}1.5-2 \\
\mathrm{~m}\end{array}$ & 8.5 \\
\hline $\mathbf{S 3}$ & Kireçli bölge & $2 \mathrm{~m}$ & 9.0 \\
\hline $\mathbf{S 4}$ & Kireçli bölge & $4 \mathrm{~m}$ & 8.5 \\
\hline
\end{tabular}

Her bir sediment örneğinden steril şartlar altında $500 \mu 1$ alınarak steril edilmiş $4.5 \mathrm{~mL}$ ringer solüsyonu içeren boncuklu tüplere aktarılmıştır. Dekontaminasyon işlemleri sonrasında seri sulandırma yapılarak $10^{-4}$ 'e kadar örneklerin dilüsyonları hazırlanmıştır (Sembiring, 2000; Sivakumar, 2008).

Her bir dilüsyondan $0.2 \mathrm{~mL}$ alınan çözeltiler, siklohekzimid $\left(50 \mu \mathrm{g} \mathrm{mL}^{-1}\right)$, rifampisin $(0.5 \mu \mathrm{g}$ $\left.\mathrm{mL}^{-1}\right)$ ve nalidiksik asit $\left(10 \mathrm{mg} \mathrm{mL}^{-1}\right)$ ilaveli tripton yeast glukoz ekstrakt agar (TYGEA), yeast malt agar (ISP 2), SM3 agar, nişasta kazein agar (SCA) ve glukoz maya malt ekstrakt agar (GYMEA) yüzeyine inoküle edilmiştir. Her bir dilüsyon için 2 plak hazırlanmıştır. İnokülasyonlu plaklar, $\mathrm{O}_{2}$ girişine izin verecek şekilde $30{ }^{\circ} \mathrm{C}^{\prime}$ deki etüvde 6-8 hafta süreyle inkübasyona 
bırakılmıştır.

Petrilerdeki aktinobakteri benzeri kolonileri belirleyebilmek için makroskobik ve mikroskobik (100x büyütme; ZEISS/Primo Star) incelemeler yapılmıştır. Aktinobakteri ve benzeri koloniler saflaştırılarak \% 30 gliserol içine aktarılmış ve $-18^{\circ} \mathrm{C}$ 'de stoklanmıştır.

\subsection{Genomik DNA İzolasyonu, 16S rDNA Gen Bölgesinin Analizi}

Aktinobakteri izolatlarının genomik DNA'ları; DNA İzolasyon Kiti (İnvitrogen,USA) kullanılarak elde edilmiştir. 16S rDNA gen bölgesinin amplifikasyonu için 27F (5'AGAGTTTGATCMTGGCTCAG-3') ve 1525R (5'AAGGAGGTGWTCCARCC-3') primerleri kullanılmıştır (Özdemir Kocak, 2019). 16S rDNA gen bölgesinin baz dizileri MacroGen firması tarafından ABI 3730XL otomatik baz dizi cihazı ile belirlenmiştir. Mega 7 (Kumar ve ark., 2016) paket programı kullanılarak 5 farklı primerden elde edilen diziler birleştirilmiş ve belirsiz bölgelerin olduğu baz dizileri veri setinden uzaklaştırılmıştır. Elde edilen 16S rDNA baz dizilimi verileri, Ez Taxon Server (https://www.ezbiocloud.net/) ve NCBI (https://www.ncbi.nlm.nih.gov/) sunucuları kullanılarak analiz edilmiştir. Ez Taxon Server kullanılarak en yakın akraba organizmaların fasta formatında 16S rDNA gen dizileri elde edilmiştir. Mega 7 programında 16S rDNA gen bölgesi baz dizilerinin çoklu hizalaması sonrasında filogenetik soy ağaçları neighborjoining (Saitou ve Nei, 1987) algoritması ile uzaklık matriksi Jukes-Cantor metodu kullanılarak oluşturulmuştur (Jukes ve Cantor, 1969).

\subsection{Antimikrobiyal Aktivite Testi}

Çalışmada, 2 Gram negatif bakteri (E.coli W3110, P. vulgaris NRRL B-123), 2 Gram pozitif bakteri (B. subtilis IMG 22, S. aureus ATCC 25923), 2 maya (C. albicans ATCC 1326, S. cerevisiae ATCC 9763) ve 2 fungus (A. parasiticus NRLL 465, Fusarium sp.) kullanılmıştır. Aktinobakteri suşlarının antibiyotik ilavesiz modifiye edilmis Bennett's Agar (Jones, 1949) yüzeyine inokülasyonu, nokta ekim yöntemi ile yapılmıştır (Williams ve Cavanaugh, 1983). İnokülasyonlu plaklar, $28{ }^{\circ} \mathrm{C}^{\prime}$ de 2 gün süreyle inkübasyona bırakılmıştır. Gelişen koloniler üzerine, 3-5 ml'lik kloroform dökülmüş ve kloroformun buharlaşması için beklenilmiştir. Ölü koloniler üzerine nutrient broth içerisinde 1-2 gün süreyle gelişen patojen test organizmaları yayma plak yöntemiyle inoküle edilmiştir. $28{ }^{\circ} \mathrm{C} 1$ günlük inkübasyondan sonra koloni çevresinde test patojenlerine karşı oluşan inhibisyon zonları kumpas ile ölçülerek kaydedilmiştir. 


\subsection{Aktinobakteri İzolatlarının Bitki Gelişim Aktiviteleri}

İzolatlar, indol asetik asit (IAA) varlığı, serbest azotu (N) fikse edebilme yeteneği, inorganik fosfatı çözebilme yetenekleri ve kazeinaz aktiviteleri yönünden incelenmiştir. Test izolatları, indol asetik asit tayini için $100 \mathrm{mg}$ / L L-triptofan eklenmiş Luria-Bertani (LB) broth'ta geliştirilmiştir. Kontrol grubunda ise triptofansız LB broth kullanılmıştır. Suşlar karanlıkta $30^{\circ} \mathrm{C}^{\prime}$ de 7 gün inkübe edilmiştir. İnkübasyonun sonunda, kültürler 10.000 rpm'de 15 dakika santrifüj edilerek elde edilen 1 mL süpernatanta $2 \mathrm{~mL}$ Salkowski çözeltisinden ( $2 \mathrm{~mL} \mathrm{FeCl}_{3}$ (\% 1.35), $49 \mathrm{~mL}$ su ve 49 mL\% 60 (v / v) perklorik asit) ilave edilmiş ve 30 dakika karanlıkta bekletilmiştir (Gordon ve Weber, 1951). Pembe renk oluşumu IAA üretimini açısından pozitif olarak değerlendirilmiştir.

İzolatların $\mathrm{N}$ fiksasyon yetenekleri hazırlanan nitrojensiz ortamda büyüyebilme özelliklerine göre belirlenmiştir. İzolatlar, 10 mL yarı katı agar (\% 1 Maya Karbon Baz ve\% 1 Noble Agar) içeren test tüplerinin içine inoküle edilmiş ve karanlıkta $28^{\circ} \mathrm{C}^{\prime}$ de 3 hafta inkübe edilmiştir. $\left(\mathrm{NH}_{4}\right) 2 \mathrm{SO}_{4}(2$ $\mathrm{g} \mathrm{L}^{-1}$ ) eklenen yarı katı agar, pozitif kontrol olarak kullanılmıştır (Trujillo ve ark., 2010).

İsolatların kazeinaz aktivitesi nütrient agar ve skim milk agar kullanılarak Kazanas'ın modifiye edilen prosedürüne göre belirlenmiştir. İzolatlar bu ortamlara nokta inokülasyon yöntemi ile ekilmiş ve 3 gün $37{ }^{\circ} \mathrm{C}$ 'de inkübe edilmiştir. İzolatların aktivitesi açık zon oluşumu ile belirlenmiştir (Kazanas, 1968).

İnorganik fosfatın çözünürlüğü, Ulusal Botanik Araştırma Enstitüleri fosfat-bromofenol mavisi (NBRIPBPB) ortamında (Nautiyal, 1999) yetiştirilen test suşlarının kültürlerinde incelenmiştir. 30 ${ }^{\circ} \mathrm{C}^{\prime}$ de 7 günlük bir inkübasyon periyodunu takiben fosfatı çözündüren kolonilerde, berrak zon bölgesi oluşumu pozitif sonuç olarak değerlendirilmiştir.

\section{Bulgular ve Tartışma}

Sakarya Nehri'nin doğduğu kaynaktan toplanan sedimentlerden mikroorganizma izolasyonu seçici besiyerleri ve farklı antibiyotikler kullanılarak gerçekleştirilmiştir. Sediment örnekleri antibiyotik ilaveli tripton maya glukoz ekstrakt agar, ISP 2 agar, SM3 agar, SC agar ve glukoz maya malt ekstrakt agar yüzeyine inoküle edilmiştir.

6-8 hafta inokülasyona tabi tutulan sediment örneklerinden GYME besiyeriden 4 izolat, SM3 besiyeriden 13 izolat olmak üzere toplamda 17 mikroorganizma elde edilmiştir. İzole edilen 17 izolatın 14 tanesinin Micromonospora cinsi ile, 2 tanesinin Saccharomonospora cinsi ve 1 tanesinin Cellulomonas cinsi ile ilişkili olduğu belirlenmiştir. Sedimentten yapılan Aktinobakteri izolasyonunda SM3 besiyeri en uygun besiyeri olarak görülürken ISP 2, TYGE agar ve SC agarın kullanımının uygun olmadığı belirlenmiştir. Bizim çalışmamızda SC agar ile izolasyon 
gerçekleştirilememesine rağmen Özcan'ın (2019) yapmış olduğu çalışmada bu besiyeri kullanılmış ve Aktinobakteri izolasyonu gerçekleştirilmiştir. Bu farklılığın nedeni, Özcan'ın çalışmasında göl sedimenti kullanması ya da kullanılan inhibisyon ajanlarının farklı olmasından kaynaklanabileceği düşünülmektedir.

Aktinobakteriler; en yaygın olarak toprakta bulunmaktadırlar. Toprak dışında deniz, göl, nehir, magrove sedimenti (Baskaran ve ark., 2011; Arango ve ark., 2018; Özcan, 2019), krater çevresi (Tapia-Vázquez ve ark., 2020), endofitik bitkilerin kök, gövde ve yaprak kısımları (Özdemir Koçak, 2019), insan ve hayvan bağırsağı (Barka ve ark., 2016) veya aktif çamur (Seviour ve ark., 2008) gibi oldukça farklı alanlardanda yaşayabildikleri belirlenmiştir. Tatlı su nehir kaynağından izolasyon ve aktif metabolit çalışmaları da bulunmaktadır (Zothanpuia ve ark., 2018; Arango ve ark., 2018).

Sediment izolasyonu sonucu makroskobik ve mikroskobik görüntülerine göre seçilen 17 izolatın 16S rDNA gen bölgesi analizleri ve antimikrobiyal aktiviteleri ile birlikte bazı bitki gelişim teşvik testleri uygulanmıştır.

\subsection{S rDNA Gen Bölgesinin PCR Amplifikasyonu}

Çalışmada elde edilen 17 Aktinobakteri benzeri izolatın taksonomik posizyonu 16S rDNA gen dizisi analizleri ile belirlendi. Her izolatın 16S rDNA gen dizisi EzBioCloud ve NCBI web sunucularındaki veritabanları ile karşılaştırıldı. Test izolatlarının 16S rDNA gen bölgesi baz dizi analizi sonuçlarına göre S2S24 izolatının Cellulomonas cins üyesi olduğu ve \% 98.6 benzerlik oranıyla Cellulomonas aerilata'ya komşu olduğu belirlenmiştir. Cellulomonas sp. S2S24 suşunun en yakın akraba tip türüne 19 nükleotid farklılığı gösterdiği tespit edilmiştir (Şekil 1). Cellulomonas cinsi üyesi olan S2S24 izolatının yüksek nükleotit farklı1ığa sahip olması nedeniyle olası yeni tür adayıdır. 2019 yılında tanımlanan Cellulomonas algicola tatlı su alginden izole edilen yeni bir türdür (Yamamura ve ark., 2019).

Micromonospora sp. S2S31, Micromonospora sp. S1S23, Micromonospora sp. S1S35, Micromonospora sp. S2S22, Micromonospora sp. S1S21 ve Micromonospora sp. S2S23 izolatlarının \% 90.7 - 99.6 oranlarında M. ovatispora ile yakın ilişkili olduğu ve 6-130 nükleotid farklılığa sahip oldukları belirlenmiştir. Micromonospora sp. S3S31, Micromonospora sp. S1S34, Micromonospora sp. S1S33 ve Micromonospora sp. S1S31 izolatlarının \% 99.1 - 99.4 oranlarında M. spongicola ile yakın ilişkili olduğu ve 11-13 nükleotid farklılığa sahip oldukları tespit edilmiştir. Micromonospora sp. S1G21 izolatının \% 99.6 oranında M. ureilytica ile yakın ilişkili olduğu ve 6 nükleotid farklılığa sahip olduğu belirlenmiştir. Micromonospora sp. S2G33, 
Micromonospora sp. S2G34 ve Micromonospora sp. S2G35 izolatlarının \% 99.4-99.9 oranlarında M. vinacea ile yakın ilişkili olduğu ve 2-8 nükleotid farklılığa sahip oldukları görülmüştür (Şekil 2). 14 adet Micromonospora cinsine ait izolatın 6 tanesinin Micromonospora ovatispora, 4 tanesinin Micromonospora spongicola, 3 tanesinin Micromonospora vinacea ve 1 tanesinin de Micromonospora ureilytica ile ilişkili olduğu bulunmuştur. S1S32, S3S31 ve S1S33 izolatlarının Micromonospora spongicola $\mathrm{S} 3-1^{\mathrm{T}}$ suşu ile sirasıyla \% 99.2 benzerlik ve 11 nükleotid farklılığ1, \% 99.2 benzerlik ve 12 nükleotid farklılığ 1 \% 99.1 benzerlik ve 13 nükleotid farklılığı olduğu belirlenmiştir. Nükleotid farklılıkları göz önüne alındığında söz konusu izolatların yeni tür adayı olarak değerlendirilmeleri gerektiği belirlenmiştir. Daha çok nehir sedimentinden tanımlanan Micromonospora türleri (Phongsopitanun ve ark., 2015; Phongsopitanun ve ark., 2016; Veyisoglu ve ark., 2020) mevcut olsa da nehir sedimentinden izole edilmiş olan Micromonospora fluminis (Pozo ve ark., 2020) türü de bulunmaktadır.

Saccharomonospora sp. S2S21 ve S2S41 izolatlarının \%98.7-98.8 oranında Saccharomonospora azurea'a komşu olduğu ve 15-17 nükleotid farklılı̆̆ı olduğu belirlenmiştir (Şekil 3). Saccharomonospora cinsi üyesi olduğu belirlenen S1S41 ve S2S21 izolatlarının aralarında 3 nükleotid farklılığı bulunmaktadır ve aynı morfolojik karakterlere sahip olan bu iki izolatın yeni tür olma ihtimali bulunmaktadır. Günümüzde 16 türü bulunan bu cins üyelerinin çoğu topraktan izole edilmiştir. Deniz (Liu ve ark., 2010; Veyisoglu ve ark., 2013; Zhang ve ark., 2013), göl (Li ve ark., 2016 ) ve balık havuzu sedimentinden (Tseng ve ark., 2018) elde edilerek tanımlanan türleri bulunmaktadır. Literatürde henüz bu cinse ait tatlı su veya nehir sedimentinden elde edilerek tanımlanan bir tür bulunmamaktadır. 


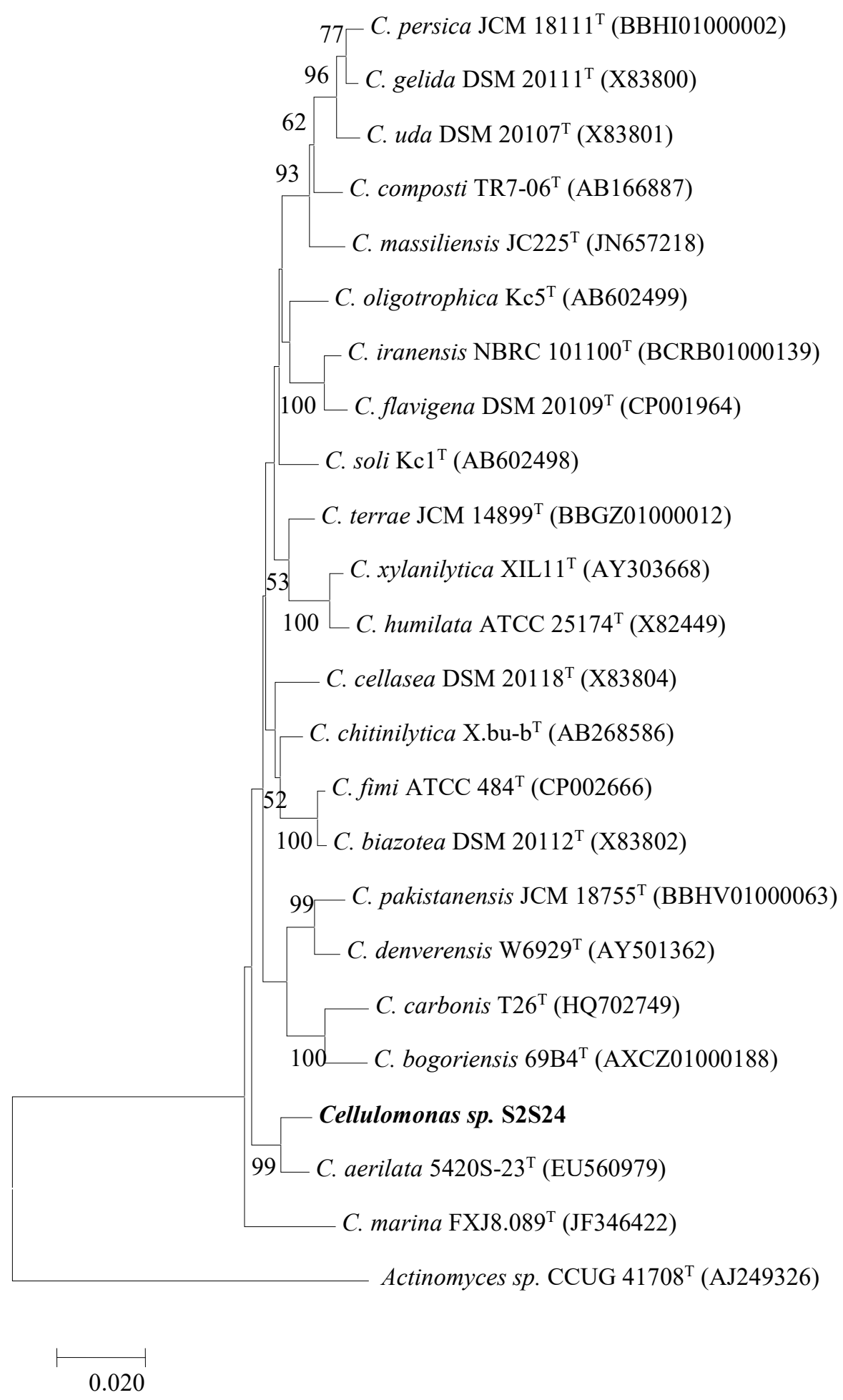

Şekil 1. Cellulomonas cinsine ait test organizmaları ve tip türlerinin 16S rDNA baz dizi analizine dayalı neighbour-joining (Saitou ve Nei, 1987) filogenetik soyağacı. Dış grup olarak Actinomyces sp. CCUG $41708^{\mathrm{T}}$ (AJ249326) kullanılmıştır. 


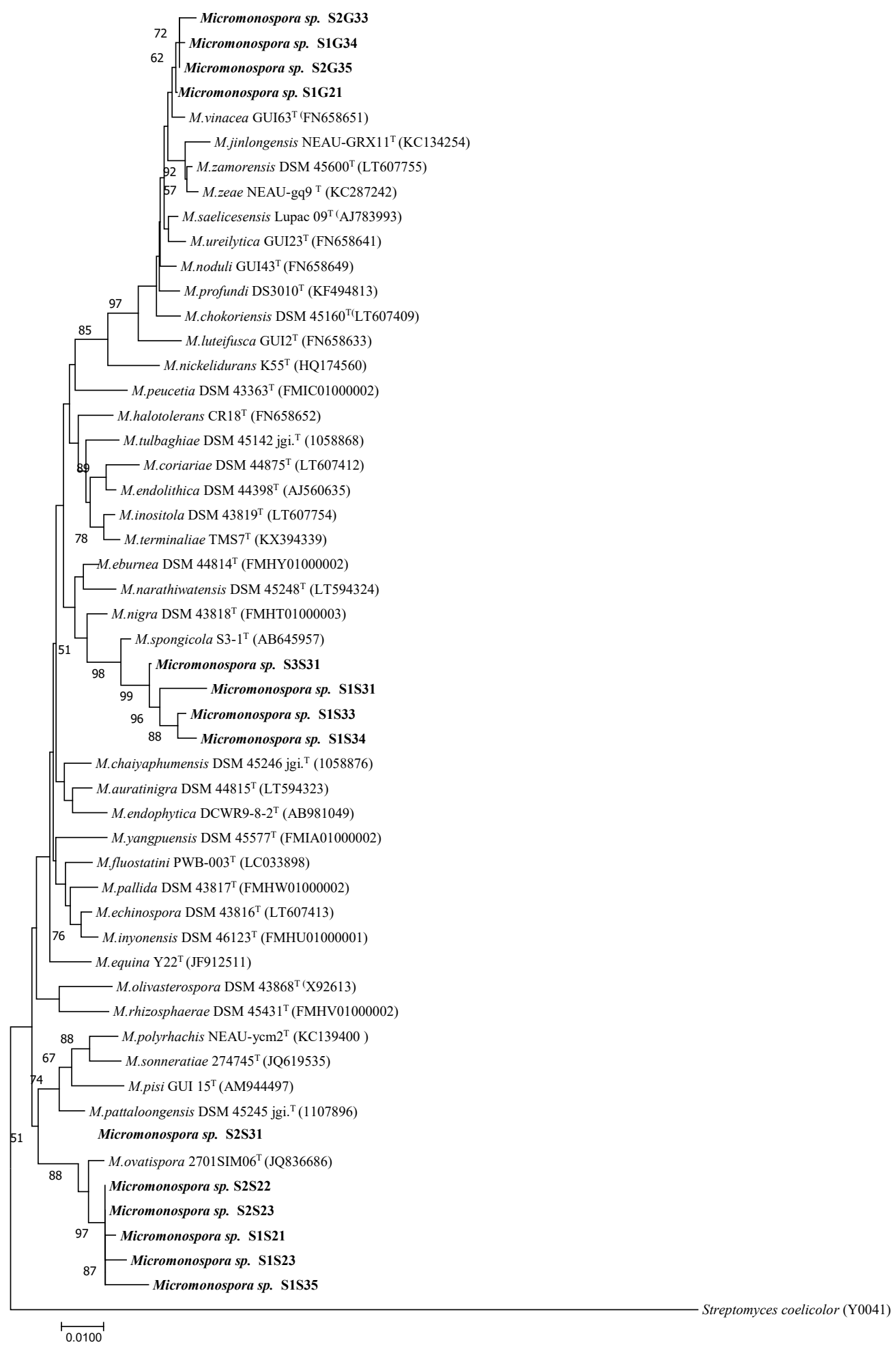

Şekil 2. Micromonospora vinacea türü ile ilişkili test organizmaları ve tip türlerinin $16 \mathrm{~S}$ rDNA baz dizi analizine dayalı neighbour-joining (Saitou ve Nei, 1987) filogenetik soyağacı. Dış grup olarak Streptomyces coelicolor Y00411 kullanılmıştır. 


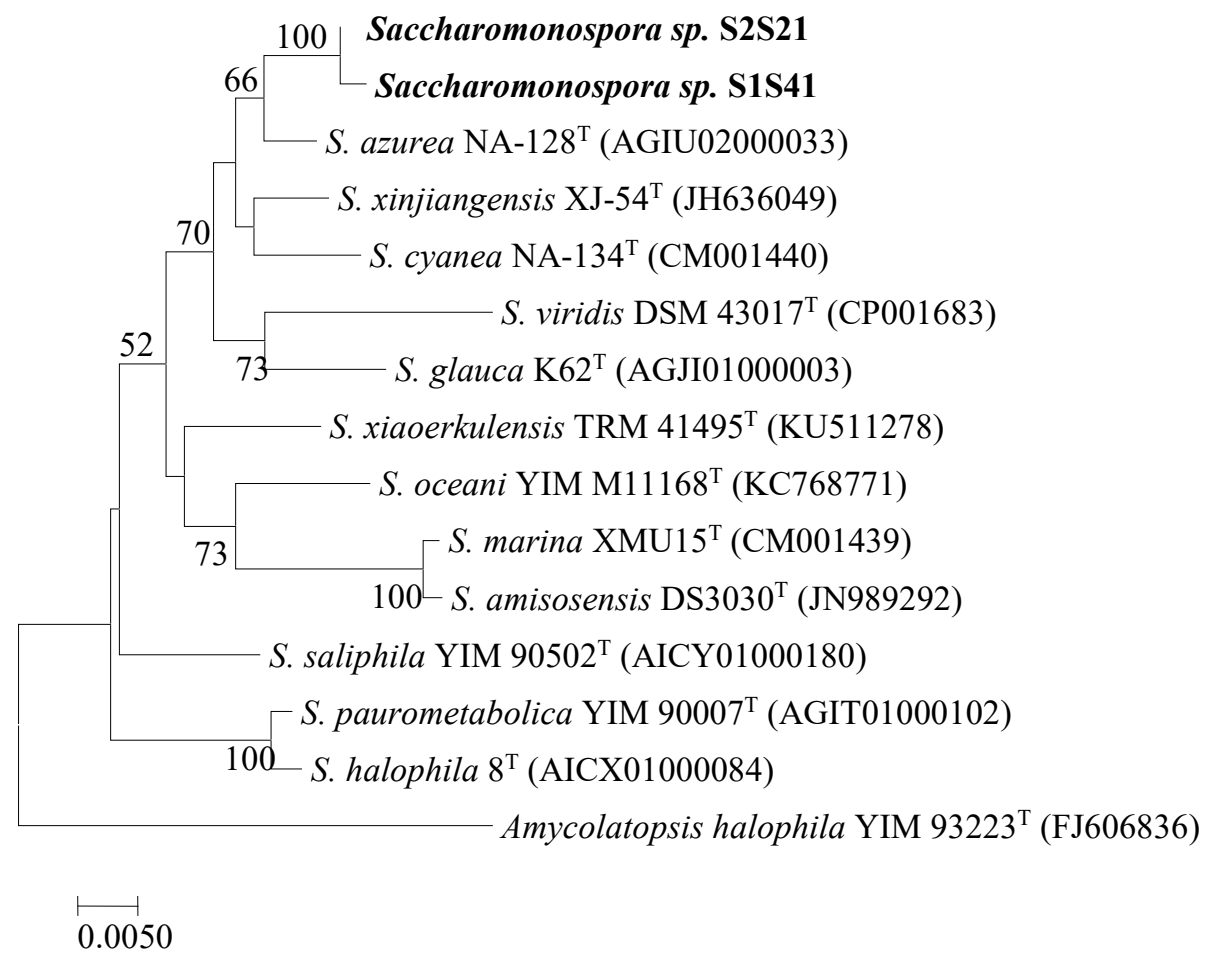

Şekil 3. Saccharomonospora cinsine ait test organizmaları ve tip türlerinin 16S rDNA baz dizi analizine dayalı neighbour-joining (Saitou ve Nei, 1987) filogenetik soyağac1. Dış grup olarak Amycolatopsis halophila YIM 93223 ${ }^{\mathrm{T}}$ (FJ606836) kullanılmıştır.

\subsection{Antimikrobiyal Test Sonuçları}

Test izolatlarının antimikrobiyal etkisi farklı patojen mikroorganizmalar kullanılarak belirlenmiştir. S3S31 Micromonospora sp. izolatının 5 patojene karşı (S. aureus, B. subtilis, C. albicans, S.cerevisiae ve Fusarium sp.) etkili inhibisyon zonu verdiği belirlenmiştir. S1S23 izolatının 3 patojene karşı (S. aureus, C. albicans ve $S$. cerevisiae) etkili inhibisyon zonu verdiği, S1S21 izolatının 2 patojene karşı (C. albicans ve $S$. cerevisiae) etkili inhibisyon zonu verdiği ve S2G33 izolatının da 2 patojene karşı (E. coli ve $S$. cerevisiae) etkili inhibisyon zonu oluşturduğu tespit edilmiştir. Micromonospora sp. ile ilişkili olan 5 organizma ise sadece 1 patojene karşı etkili inhibisyon zonu vermişlerdir. Bu izolatlardan S2G33 izolatı E. coli'yi $30 \mathrm{~mm}$ zon oluşturarak inhibe etmiştir. S1G34 izolatı da A. parasiticus'u $20 \mathrm{~mm}$ zon çapı oluşturmuştur. Test sonuçları değerlendirildiğinde, test edilen 17 organizmadan 7 tanesinin hiçbir patojene karşı etkisinin olmadığı gözlenmiştir. En yüksek inhibisyon zonunu S3S31 izolatı S. cerevisiae (35 $\mathrm{mm}$ ) üzerinde oluşturmuştur (Tablo 2). Yapılan analizler sonucu Cellulomonas cinsi ile ilişkilendirilen S2S24 izolatının hiçbir patojene karşı etki göstermediği belirlenmiştir. Micromonospora cinsi arasında en yüksek inhibisyon zonu veren izolat $M$. spongicola ile ilişkilendirilmiş olan S3S31 ve en düşük 
inhibisyon zonu verenler M. ovatispora ile ilişkili olan S1S21, S2S23 ve S1S23 izolatlarıdır. Micromonospora cinsine ait izolatlardan S2G33 kodlu izolat dışındakiler Gram negatif (E. coli, 30 $\mathrm{mm}$ ) patojenlere etki göstermemiş olup daha çok Gram pozitif bakterilere, maya ve funguslara etkileri görülmüştür.

Metisilin veya rifamsin dirençli organizma gruplarının artması ve alternatif antimikrobiyal ilaç arayışlarındaki talebin artışı nedeniyle mikroorganizmalardan sekonder metabolit taraması güncelliğini korumaktadır. Tüm mikrobiyal metabolitlerin \% 45'i filamentli aktinobakteriler tarafından üretilmektedir. 10.000'den fazla biyoaktif bileşiğin 7600’ü (\%75) Streptomyces ve 2500 metabolit ise Micromonospora, Actinomadura, Nocardia ve Streptoverticillium gibi nadir aktinobakteriler tarafından üretilmektedir (Berdy, 2005). Özellikle toprak dışındaki ekstrem ortamlardan nadir aktinomisetlerin yeni selektif izolasyon teknikleri ve nadir aktinobakterileri tarama çalışmaları yeni ve faydalı biyoaktif bileşiklerin keşfine olanak sağlamaktadır (Azman ve ark., 2015; Gärtner ve ark., 2016). Metisilin dirençli S. aureus'a karşı etkili olan rifamycinS ve rifamycinS'in geometrik izomeri Micromonospora rifamycinica AM105 suşundan elde edilmiştir. Benzer şekilde Micromonospora izolasyonu ve biyoaktif bileşik taramaları birçok çalışmanın konusu olmuştur (Phongsopitanun ve ark., 2015; Ichiwaki ve ark., 2017; Veysioğlu ve ark., 2020). Yaptığımız izolasyon çalışması ile de olası yeni türlerin yanında antimikrobiyal etkinliğe sahip suşlarda elde edilmiştir. Özellikle Micromonospora suşlarının Gram negatif organizmalardan ziyade Gram pozitif bakterilere, maya ve funguslar üzerine etki gösterdiği ve bu sonuçların literatür ile uyumlu olduğu belirlenmiştir. Karabi ve arkadaşlarının yaptığ 1 çalışmada, Cellulomonas cinsi üyelerinin izolasyonu yapılmış ve elde edilen izolatların antimikrobiyal aktiviteleri çalışılmıştır. Elde edilen sonuçlarda test edilen izolatların farklı patojenlere karşı etkin olduğunu belirlemişlerdir (Karabi ve ark., 2016). Fakat yaptığımız çalışmada Cellulomonas suşunun kullanılan test patojenlerine karşı etkin olmadığı belirlenmiştir. Saccharomonospora sp. üyelerinin antimikrobiyal etkinliğinin belirlendiği bir çalışmada da Gram pozitif ve mantarlardan ziyade izolatların gram negatif patojenlere etkin olduğu belirlenmiştir. Çalışmamızda elde edilen iki Saccharomonospora sp. suşundan S1S41 kodlu olan organizmanın hiçbir patojene etki etmediği S2S21 kodlu organizmanın ise $C$. albicans ve $S$. cerevisiae'a etki gösterdiği belirlenmiştir. Literatürdeki taramalardan farklı sonuçlar elde edilmesi Saccharomonospora sp. suşlarımızın olası yeni birer tür olma ihtimalini arttırmaktadır. Benzer şekilde farklı çalışmalarla ticari önemi yüksek pek çok metabolit keşfide yapılmıştır (Huang ve ark., 2008, Kyeremeh ve ark., 2014; Williams ve ark., 2017; Le ve ark., 2017; Ibrahim ve ark., 2017, Ribeiro ve ark., 2020). 
Tablo 2. Test izolatlarının antibakteriyel ve antifungal aktivite sonuçları

\begin{tabular}{|c|c|c|c|c|c|c|c|c|}
\hline & E.coli & $\begin{array}{c}P . \\
\text { vulgaris }\end{array}$ & $\begin{array}{c}S . \\
\text { aureus }\end{array}$ & $\begin{array}{r}B . \\
\text { subtilis }\end{array}$ & $\begin{array}{c}C . \\
\text { albicans }\end{array}$ & $\begin{array}{c}S . \\
\text { cerevisiae }\end{array}$ & $\begin{array}{c}A . \\
\text { parasiticus }\end{array}$ & $\begin{array}{c}\text { Fusarium } \\
\text { sp. }\end{array}$ \\
\hline S2S21 & $\begin{array}{l}- \\
- \\
\end{array}$ & --- & --- & --- & $\begin{array}{c}10 \\
\mathrm{~mm}\end{array}$ & $30 \mathrm{~mm}$ & --- & --- \\
\hline S3S31 & $\begin{array}{l}-- \\
- \\
\end{array}$ & --- & $\begin{array}{c}13 \\
\mathrm{~mm}\end{array}$ & $20 \mathrm{~mm}$ & $\begin{array}{c}26 \\
\mathrm{~mm}\end{array}$ & $35 \mathrm{~mm}$ & --- & $30 \mathrm{~mm}$ \\
\hline S1S33 & $\begin{array}{l}-- \\
-\end{array}$ & --- & --- & --- & --- & --- & --- & --- \\
\hline S1S34 & $\begin{array}{l}-- \\
-\end{array}$ & --- & --- & --- & --- & --- & --- & --- \\
\hline S1S35 & $\begin{array}{l}-- \\
-\end{array}$ & --- & --- & --- & --- & --- & --- & --- \\
\hline S2S24 & $\begin{array}{l}-- \\
-\end{array}$ & --- & --- & --- & --- & --- & --- & --- \\
\hline S1G34 & $\begin{array}{l}-- \\
-\end{array}$ & --- & --- & --- & --- & --- & $20 \mathrm{~mm}$ & --- \\
\hline S1G21 & $\begin{array}{l}-- \\
-\end{array}$ & --- & --- & --- & --- & --- & --- & --- \\
\hline S1S31 & $\begin{array}{l}-- \\
-\end{array}$ & --- & --- & --- & --- & $25 \mathrm{~mm}$ & --- & --- \\
\hline S1S23 & $\begin{array}{l}-- \\
- \\
\end{array}$ & --- & $\begin{array}{c}20 \\
\mathrm{~mm}\end{array}$ & --- & $\begin{array}{c}10 \\
\mathrm{~mm}\end{array}$ & $25 \mathrm{~mm}$ & --- & --- \\
\hline S2G33 & $30 \mathrm{~mm}$ & --- & --- & --- & -- & $22 \mathrm{~mm}$ & --- & --- \\
\hline S2S23 & $\begin{array}{l}-- \\
- \\
\end{array}$ & --- & --- & --- & --- & $10 \mathrm{~mm}$ & --- & --- \\
\hline S2G35 & $\begin{array}{l}-- \\
- \\
\end{array}$ & --- & --- & --- & --- & $18 \mathrm{~mm}$ & --- & --- \\
\hline S1S41 & $\begin{array}{l}-- \\
- \\
\end{array}$ & --- & --- & --- & --- & --- & --- & --- \\
\hline S2S22 & $\begin{array}{l}-- \\
- \\
\end{array}$ & --- & --- & --- & --- & --- & --- & --- \\
\hline S2S31 & $\begin{array}{l}-- \\
- \\
\end{array}$ & --- & --- & --- & $\begin{array}{c}14 \\
\mathrm{~mm}\end{array}$ & --- & --- & --- \\
\hline S1S21 & $\begin{array}{l}-- \\
-\end{array}$ & --- & --- & --- & --- & --- & --- & --- \\
\hline
\end{tabular}

\section{3. Aktinobakteri İzolatlarının Bitki Gelişim Aktiviteleri}

Sakarya nehir sedimentinden izole edilmiş olan Aktinobakteri izolatlarının bitki gelişim teşvik özellikleri incelenmiş ve Tablo 3 'te verilmiştir. IAA testinde Saccharomonospora sp. S1S41, Micromonospora suşlarından S2G33, S1S21, S1S33, S2G35, S1S35 ve S2S23 pembe renk oluşumu ile pozitif sonuç vermiştir. Diğer Aktinobakteri suşlarının ise IAA üretim kapasitelerinin olmadığı belirlenmiştir.

N’u fikse edebilme özellikleri açısından Aktinobakteri suşlarının Saccharomonospora sp. 
S1S41, Micromonospora sp. S1S21, Micromonospora sp. S1G21, Micromonospora sp. S1S35 ve Cellulomonas sp. S2S24 haricinde hepsinin pozitif sonuç verdiği belirlenmiştir. Bu suşlar içinde S1S23 suşunun zayıf pozitif olduğu tespit edilmiştir.

Kazeinaz aktivitesi gösteren Micromonospora sp. S2G33 ve Micromonospora sp. S1S21 suşları dışında diğer suşlar negatif sonuç vermiştir. İnorganik fosfatı çözebilme yeteneğinin hiçbir suşta olmadığg görülmüştür (Tablo 3).

Tablo 3. Aktinobakteri suşlarının bitki gelişim teşvik edici özellikleri

\begin{tabular}{|c|c|c|c|c|}
\hline Izolat Kodu & Azok Fiksasyonu & IAA Testi & Kazeinaz Testi & Fosfat Çözebilme \\
\hline S1S41 & - & + & - & - \\
\hline S2G33 & + & + & + & - \\
\hline S3S31 & + & - & - & - \\
\hline S1S21 & - & + & + & -- \\
\hline S1S33 & + & + & -- & - \\
\hline S1G34 & + & - & - & - \\
\hline S1S34 & + & - & - & - \\
\hline S1G21 & - & - & - & -- \\
\hline S1S34 & + & -- & -- & - \\
\hline S1S31 & + & - & - & -- \\
\hline S2G35 & + & + & -- & -- \\
\hline S1S35 & - & + & -- & -- \\
\hline S2S21 & + & -- & -- & - \\
\hline S2S23 & + & + & - \\
\hline S1S23 & + (zay1f) & -- & - \\
\hline S2S22 & + & -- & - \\
\hline S2S24 & - & - & - \\
\hline
\end{tabular}

Mikroorganizmaların bitki gelişim teşvik edici özellikleri ile ilgili çalışmaların çoğunluğu toprak yada rizosfer bakterileri üzerinedir (Sathya ve ark., 2017; Özdemir Koçak., 2019). Wang ve arkadaşlarının yaptığ suşlarının izolasyonu ve bunların yüksek tortu organik madde yükü altında Vallisneria natans üzerindeki büyümesini teşvik edici etkisi incelenmiştir (Wang ve ark., 2021). Göl restrasyonu ve ekosistem yenilenmesinde önemli olan makrafitlerin gelişimini arttırılması hedeflenen bu çalışmada diğer toprak ve rizosfer çalışmalarından farklı olarak su altındaki makrofit köklerinden bakteri izolasyonu yapılmıştır. Son dönemde krater çevresi ve Morocco gibi ekstrem ortamlardan izolasyon ve bu ortamlardan izole edilen mikroorganizmaların bitki gelişimi teşvik özelliklerini incelemeye yönelik çalışmalarda yapılmıştır (Nafis ve ark., 2019; Tapia-Vázquez ve ark., 2020). Farklı mikroorganizma gruplarının bitki gelişim teşvik özellikleri üzerine birçok çalışma bulunmaktadır (de Souza ve ark., 2015).

Ancak literatür taramasında sedimentten elde edilen izolatların bitki gelişimini teşvik özellikleri üzerine herhangi bir çalışmanın olmadığı belirlenmiştir. Bu nedenle ilk kez bu çalışma ile sedimentten 
izole edilen suşların bitki gelişimini teşvik edici özellikleri incelenmiştir. Yapılan testler sonucunda N fiksasyonu açısından Micromonospora suşlarının etkin olduğu, Saccharomonospora suşlarından S1S41 negatifken S2S21'in pozitif olduğu belirlenmiştir. IAA testinde ise 6 Micromonospora suşu ile S1S41 Saccharomonospora suşu pozitif sonuç vermiştir. Kazeinaz test sonuçlarında 2 Micromonospora suşunun pozitif sonuç verdiği belirlenmiştir. Hiçbir izolatın inorganik fosfatı çözebilme yeteneğine sahip olmadı̆̆ı belirlenmiştir. N fiksasyonu ile ilgili yapılan çalışmalarda Micromonospora cins üyelerinin N fikse edebilme yeteneklerinin olduğu belirtilmiş ve elde ettiğimiz sonuçların literatürle uyumlu olduğu gözlenmiştir (Trujillo ve ark., 2010 ). Streptomyces, Arthrobacter, Rhodococcus and Micromonospora cinslerine ait üyelerin İnorganik fosfatı çözebilme yeteneği olduğu literatürde belirtilmiştir (Nafis ve ark., 2019). Bununla birlikte, deniz veya kurak ortamlardan izole edilen aktinobakterilerin P-çözündürme etkinliği konusunda çok sınırlı araştırma yapılmıştır. IAA üretimi açısından Actinomyces sp., Frankia sp., Nocardia sp., ve Streptomyces spp.'lerin oldukça etkin olduğu bilinmektedir (Wani ve Gopalakrishnan, 2019). Sediment veya sucul ortamlardan elde edilen aktinobakteilerin IAA üretimi ve kazeinaz aktivitesi üzerine yapılmış çalışılmaya rastlanılmamıştır. $\mathrm{Bu}$ açıdan elde edilen sonuçlar ilk kez literatüre kazandırılması açısından oldukça önemlidir.

\section{Sonuçlar ve Öneriler}

Nadir aktinomiset taramalarında özellikle son dönemde toprak ve rizosfer dışındaki alanların tercih edilmesi nedeniyle bu çalışmada, farklı bir ortam olan nehir sedimenti kullanılmıştır. Aktinomiset çeşitliliğini belirleyebilmek amacıyla da selektif ajanlar ve seçici ortamlar kullanılmıştır. Nadir aktinomiset eldesinde SM3 ortamının daha başarılı olduğu ve farklı çalışmalarda da kullanılabileceği öngörülmektedir. İzolatların moleküler tanımlamasında 16S rDNA dizi analizleri kullanılmıştır. Elde edilen sonuçlardan S2S24 Cellumonas sp. (19 nt farklılığ1), S2S21 Saccharomonospora sp. (17 nt farklılı̆̆ı) ile S1S33 ve S1G21 Micromonospora sp. (13-15 nt farklılığı) suşlarının yeni birer tür olabileceği belirlenmiştir. Bu suşlar, nümerik, kemotaksonomik ve genomik analizlerinin tamamlanmasının ardından yeni birer tür olarak literatüre kazandırılacaktır. Bioaktif bileşik yönünden yüksek aktiviteye sahip olan S1S23, S2G33, S3S31 ve S1G34 suşların etken maddelerinin belirlenmesine yönelik çalışmaların yapılması hedeflenmektedir. Bitki gelişimini teşvik edici özelliklere sahip olan S1S21, S1S33, S2G33, S1S41, S2G35ve S2S23 kodlu suşların bitkilerdeki etkilerinin belirlenmesi düşünülmektedir. 


\section{Teşekkür}

Bu çalışma Bilecik Şeyh Edebali Üniversitesi BAP tarafından 2016-01.BŞEÜ.13-01.kodlu proje ile desteklenmiştir.

\section{Yazarların Katkısı}

Tüm yazarlar çalışmaya eşit katkıda bulunmuştur.

\section{Çıkar Çatışması Beyanı}

Yazarlar arasında herhangi bir çıkar çatışması bulunmamaktadır.

\section{Araştırma ve Yayın Etiği Beyanı}

Yapılan çalışmada araştırma ve yayın etiğine uyulmuştur.

\section{Kaynaklar}

Arango, C., Acosta-Gonzalez, A., Parra-Giraldo, C.M., Sánchez-Quitian, Z.A., Kerr, R., and Diaz, L.E., (2018). Characterization of Actinobacterial Communities from Arauca River Sediments (Colombia) Reveals Antimicrobial Potential Presented in Low Abundant Isolates. The Open Microbiology Journal, 12, 181-194.

Azman, A. S., Othman, I., S Velu, S., Chan, K. G., and Lee, L. H., (2015). Mangrove rare actinobacteria: taxonomy, natural compound, and discovery of bioactivity. Frontiers in Microbiology, 6, 856. Bacteriology", 2nd ed., Vol. 5, Parts A and B.

Baltz, R., (2007). Antimicrobials from actinomycetes: Back to Future. Microbe. 2, 125-131.

Barka, E. A., Vatsa, P., Sanchez, L., Gaveau-Vaillant, N., Jacquard, C., Klenk, H.P., Clément, C., Ouhdouch, Y., and van Wezel, G.P., (2016). Taxonomy, Physiology, and Natural Products of Actinobacteria. Microbiology and Molecular Biology Reviews, 80(1), 1-43

Baskaran, R., Vijayakumar, R., and Mohan, P. M., (2011). Enrichment method for the isolation of bioactive actinomycetes from mangrove sediments of Andaman Islands, India.Malays Journal Microbiology, 7(1), 26-32.

Berdy, J., (2005). Bioactive microbial metabolites. The Journal of antibiotics, 58(1), 1-26.

de Souza, R. D., Ambrosini, A., and Passaglia, L. M., (2015). Plant growth-promoting bacteria as inoculants in agricultural soils. Genetics and Molecular Biology, 38(4), 401-419.

El-Tarabily, K. A., Nassar, A. H., and Sivasithamparam, K., (2008). Promotion of growth of bean (Phaseolus vulgaris L.) in a calcareous soil by a phosphate-solubilizing, rhizosphere-competent isolate of Micromonospora endolithica. Applied soil ecology, 39(2), 161-171.

Gärtner, A., Wiese, J., and Imhoff, J. F., (2016). Diversity of Micromonospora strains from the deep Mediterranean Sea and their potential to produce bioactive compounds. AIMS Microbiology, 2(2), 205221.

Gong, Y., Bai, J. L., Yang, H. T., Zhang, W. D., and Xiong, Y.W. et al., (2018). Phylogenetic diversity and investigation of plant growthpromoting traits of actinobacteria in coastal salt marsh plant rhizospheres from Jiangsu, China. Systematic and Applied Microbiology, 41, 516-527. 
Gordon, S. A., and Weber, R. P., (1951). Colorimetric estimation of indoleacetic acid. Plant Physiology, 26(1), 192.

Guan, T. W., Lin, Y. J., Ou, M. Y., and Chen, K. B., (2020). Isolation and diversity of sediment bacteria in the hypersaline aiding lake, China. PloS one, 15(7), e0236006.

Güneş, A., Yıldırım , E., Turan , M., Kotan , R., Ekinci , M., and Argın, S., (2021). Amino Acid and Hormone Content of Plant Growth-Promoting Rhizobacteria Grown in Drought Stress Created by PEG6000. Avrupa Bilim ve Teknoloji Dergisi, 21, 95-112.

Huang, C. Y., Roessner, U., Eickmeier, I., Genc, Y., Callahan, D. L., Shirley, N., and Bacic, A., et al., (2008). Metabolite profiling reveals distinct changes in carbon and nitrogen metabolism in phosphate-deficient barley plants (Hordeum vulgare L.). Plant and Cell Physiology, 49(5), 691-703.

Ibrahim, S., (2017). Isolation, identification and antibiosis efficacy of marine thermophilic actinomycetes. Egyptian Journal of Microbiology, 52(1), 113-128.

Ichiwaki, S., Costa, A. C., Silva, E. G., Rada, L. R., Lima, F. R., Ortíz-Vera, M. P., and Padilla, G., et al., (2017). Genome sequence of Micromonospora sp. NBS 11-29, an antibiotic and hydrolytic enzyme producer, isolated from river sediment in Brazil. Genome announcements, 5(28). e00552-17.

Jones, K. L., (1949). Fresh isolates of actinomycetes in which the presence of sporogenous aerial mycelia is a fluctuating characteristic. Journal of Bacteriology, 57,141-145.

Jose, P. A., and Jha, B., (2017). Intertidal marine sediment harbours Actinobacteria with promising bioactive and biosynthetic potential, Scientific Reports, 7(1), 1-15.

Jukes T. H., and Cantor C. R., (1969). Evolution of protein molecules, Mammalian Protein Metabolism, in Munro, R.E., ed, Academic Press, New York, pp. 21-132

Karabi, B., Dipak, P., and Sankar, N. S., (2016). Marine bacteria: a potential tool for antibacterial activity. Journal Applied Environment. Microbiolology, 4, 25-29.

Kazanas, N., (1968). Proteolytic activity of microorganisms isolated from freshwater fish. Applied Microbiology, 16(1), 128-132.

Kumar, S., Stecher, G., and Tamura, K., (2016). MEGA7: Molecular Evolutionary Genetics Analysis version 7.0 for bigger datasets. Molecular Biology and Evolution, 33, 1870-1874.

Kyeremeh, K., Acquah, K. S., Sazak, A., Houssen, W., Tabudravu, J., Deng, H., and Jaspars, M., (2014). Butremycin, the 3-hydroxyl derivative of ikarugamycin and a protonated aromatic tautomer of 5'-methylthioinosine from a Ghanaian Micromonospora sp. K310. Marine Drugs, 12(2), 999-1012.

Le, T. C., Yim, C. Y., Park, S., Katila, N., Yang, I., Song, M. C., and Fenical, W., et al., (2017). Lodopyridones $\mathrm{B}$ and $\mathrm{C}$ from a marine sediment-derived bacterium Saccharomonospora sp. Bioorganic \& Medicinal Chemistry Letters, 27(14), 3123-3126.

Li, D., Chen, Z. J., Luo, X. X., Xia, Z. F., Wan, C. X., and Zhang, L. L., (2016). Saccharomonospora xiaoerkulensis sp. nov., isolated from lake sediment. International Journal of Systematic and Evolutionary Microbiology, 66(12), 5145-5149.

Liu, W., Shen, X., Liu, C., and Su, Y. C., (2010). Vibrio parahaemolyticus in granulated ark shell clam (Tegillarca granosas): accumulation from water and survival during cold storage and thermal process. International Journal of Food Science \& Technology, 45(4), 670-675.

Ludwig, W., Euzéby, J., Schumann, P., Buss, H.J., Trujillo, M.E., Kämpfer, P. and Whiteman, W.B., (2012). Road map of the phylum Actinobacteria, p 1-28., In Goodfellow M, Kämpfer P, Busse HJ, Trujillo ME, Suzuki KI, Ludwig W, WhitmanWB(ed), Bergey's manual of systematic bacteriology, vol 5.Springer-Verlag, New York,

Macagnan, D., Romeiro, R. D. S., de Souza, J. T. and Pomella, A. W. V., (2006). Isolation of actinomycetes and endospore-forming bacteria from the cacao pod surface and their antagonistic activity against the witches' broom and black pod pathogens, Phytoparasitica, 3:122-132 .

Nafis, A., Raklami, A., Bechtaoui, N., El Khalloufi, F., El Alaoui, A., Glick, B. R., and Hassani, L., et al. (2019). Actinobacteria from extreme niches in morocco and their plant growth-promoting potentials. Diversity, 11(8), 139.

Nautiyal, C. S., (1999). An efficient microbiological growth medium for screening phosphate solubilizing microorganisms. FEMS Microbiology Letters, 170(1), 265-270.

Özcan, K., (2019). Yıldız Gölü Sedimentinden İzole Edilen Aktinobakterilerin Antimikrobiyal ve Enzim 
Üretim Kapasitelerinin Araştırılması, Karadeniz Fen Bilimleri Dergisi, 9(1), 144-151.

Özdemir Koçak, F., (2019). Identification of Streptomyces strains isolated from Humulus lupulus rhizosphere and determination of plant growth promotion potential of selected strains, Turkish Journal of Biology, 43(6), 391-403.

Phongsopitanun, W., Kudo, T., Mori, M., Shiomi, K., Pittayakhajonwut, P., Suwanborirux, K., and Tanasupawat, S., (2015). Micromonospora fluostatini sp. nov., isolated from marine sediment. International journal of systematic and evolutionary microbiology, 65(12), 4417-4423.

Phongsopitanun, W., Kudo, T., Ohkuma, M., Pittayakhajonwut, P., Suwanborirux, K., and Tanasupawat, S., (2016). Micromonospora sediminis sp. nov., isolated from mangrove sediment. International journal of systematic and evolutionary microbiology, 66(8), 3235-3240.

Pozo, M. I. C., Wieme, A. D., Pérez, S. R., Maury, G. L., Peeters, C., Snauwaert, C., and Vandamme, P. A., et al. (2020). Micromonospora fluminis sp. nov., isolated from mountain river sediment. International Journal of Systematic and Evolutionary Microbiology, 70(12), 6428-6436.

Ribeiro, I., Girão, M., Alexandrino, D. A., Ribeiro, T., Santos, C., Pereira, F., and Carvalho, M. F., et al. (2020). Diversity and Bioactive Potential of Actinobacteria Isolated from a Coastal Marine Sediment in Northern Portugal. Microorganisms, 8(11), 1691.

Saitou, N., and Nei, M., (1987). The neighbor-joining method: a new method for reconstructing phylogenetic trees. Molecular biology and evolution, 4(4), 406-425.

Sathya, A., Vijayabharathi, R., and Gopalakrishnan, S., (2017). Plant growth-promoting actinobacteria: a new strategy for enhancing sustainable production and protection of grain legumes. 3 Biotechnology, 7(2), 1-10.

Sembiring, L., (2008). Selective İsolation and Characterisation of Streptomyces Associated with the Rhizosphere of the Tropical Legume Paraserianthes falcataria (L)Nielsen, Ph. D. Thesis. University of Newcastle Upon Tyne, UK (2000).

Seviour, R.J., Kragelund, C., Kong, Y., Eales, K., Nielsen, J.L., and Nielsen, P.H., (2008). Ecophysiology of the Actinobacteria in activated sludge systems. Antonie van Leeuwenhoek, 94,21-33.

Sivakumar, K., (2008). Actinomycetes. In Centre of Advanced Study in Marine Biology, Annamalai University.

Tapia-Vázquez, I., Sánchez-Cruz, R., Arroyo-Domínguez, M., Lira-Ruan, V., Sánchez-Reyes, A., del Rayo Sánchez-Carbente, M., and Folch-Mallol, J. L., (2020). Isolation and characterization of psychrophilic and psychrotolerant plant-growth promoting microorganisms from a high-altitude volcano crater in Mexico, Microbiological Research, 232, 126394.

Trujillo, M.E., Alonso Vega, P., Rodríguez, R., Carro, L., Cerda, E., and Alonso, P., et al., (2010). The genus Micromonospora is widespread in legume root nodules: the example of Lupinus angustifolius. ISME Journal, 4,1265-1281.

Tseng, M., Chiang, W. P., Liao, H. C., Hsieh, S. Y., and Yuan, G. F., (2018). Saccharomonospora piscinae sp. nov., a novel actinobacterium from fishpond sediment in Taiwan. International Journal of Systematic and Evolutionary Microbiology, 68(5), 1418-1422.

Veyisoglu, A., Sazak, A., Cetin, D., Guven, K., and Sahin, N., (2013). Saccharomonospora amisosensis sp. nov., isolated from deep marine sediment, International journal of systematic and evolutionary microbiology, 63(10), 3782-3786.

Veyisoglu, A., Carro, L., Cetin, D., Igual, J. M., Klenk, H. P., and Sahin, N., (2020). Micromonospora orduensis sp. nov., isolated from deep marine sediment, Antonie van Leeuwenhoek, 113(3), 397-405.

Wang, C., Wang, H., Li, Y., Li, Q., Yan, W., Zhang, Y., and Zhou, Q., et al., (2021). Plant growth promoting rhizobacteria isolation from rhizosphere of submerged macrophytes and their growth promoting effect on Vallisneria natans under high sediment organic matter load, Microbial Biotechnology, 14(2), 726736.

Wani, S. P., and Gopalakrishnan, S., (2019). Plant growth-promoting microbes for sustainable agriculture. In Plant Growth Promoting Rhizobacteria (PGPR): Prospects for Sustainable Agriculture, pp. 19-45. Springer, Singapore.

Williams, D. E., Dalisay, D. S., Chen, J., Polishchuck, E. A., Patrick, B. O., Narula, G., and Andersen, R. J. et al., (2017). Aminorifamycins and sporalactams produced in culture by a Micromonospora sp. isolated from a Northeastern-Pacific marine sediment are potent antibiotics. Organic letters, 19(4), 766-769.

Williams, J. E., and Cavanaugh, D. C., (1983). Chronic infections in laboratory rodents from inoculation of nonencapsulated plague bacilli (Yersinia pestis), Experientia, 39(4), 408-409.

Yamamura, H., Hayashi, T., Hamada, M., Kohda, T., Serisawa, Y., Matsuyama-Serisawa, K., and Hayakawa, M., et al., (2019). Cellulomonas algicola sp. nov., an actinobacterium isolated from a freshwater 
alga, International journal of systematic and evolutionary microbiology, 69(9), 2723-2728.

Zhang, D. F., Chen, W., He, J., Zhang, X. M., Xiong, Z. J., Sahu, M. K., and Li, W. J. et al., (2013). Saccharomonospora oceani sp. nov. isolated from marine sediments in Little Andaman, India. Antonie van Leeuwenhoek, 103(6), 1377-1384.

Zothanpuia, A. K., Passari, V. V., Leo, P. C., and Kumar, B., et al., (2018). Bioprospection of actinobacteria derived from freshwater sediments for their potential to produce antimicrobial compounds. Microbiology. Cell Factories, 17, 68. 